\title{
GMR
}

\section{Internal amplification control of PCR for the Glu1-Dx5 allele in wheat}

\author{
H.N. Heim ${ }^{1}$, E.S.N. Vieira ${ }^{2}$, L.R.T. Polo ${ }^{2}$, N.K. Lima ${ }^{1}$, G.J. Silva ${ }^{1}$, G.A. Linde', \\ N.B. Colauto ${ }^{1}$ and I. Schuster ${ }^{1,2}$ \\ ${ }^{1}$ Programa de Pós-Graduação em Biotecnologia Aplicada à Agricultura, \\ Laboratório de Biologia Molecular, Universidade Paranaense, Umuarama, \\ PR, Brasil \\ ${ }^{2}$ Coodetec, Cascavel, PR, Brasil \\ Corresponding author: G.J. Silva \\ E-mail: glacyjaqueline@prof.unipar.br \\ Genet. Mol. Res. 16 (3): gmr16039718 \\ Received May 12, 2017 \\ Accepted July 21, 2017 \\ Published August 17, 2017 \\ DOI http://dx.doi.org/10.4238/gmr16039718
}

Copyright (C) 2017 The Authors. This is an open-access article distributed under the terms of the Creative Commons Attribution ShareAlike (CC BY-SA) 4.0 License.

\begin{abstract}
One of the limiting factors in using dominant markers is the unique amplification of the target fragment. Therefore, failures in polymerase chain reaction (PCR) or non-amplifications can be interpreted as an absence of the allele. The possibility of false negatives implies in reduced efficiency in the selection process in genetic breeding programs besides the loss of valuable genetic material. Thus, this study aimed to evaluate the viability of a microsatellite marker as an internal amplification control with a dominant marker for the wheat Glu1-Dx5 gene. A population of 77 wheat cultivars/breeding lines was analyzed. Fourteen microsatellite markers were analyzed in silico regarding the formation of dimers and clamps. The biplex reaction conditions were optimized, and the Xbarc117 marker was selected as the internal amplification control with a Glu1-Dx5 marker in wheat. It was concluded that the Xbarc117 microsatellite marker was effective in the simultaneous amplification with a dominant Glu1-Dx5 marker, making biplex PCR viable in wheat for the studied markers.
\end{abstract}

Key words: Biplex PCR; High molecular weight glutenin; Microsatellite marker; SSR

Genetics and Molecular Research 16 (3): gmr16039718 


\section{INTRODUCTION}

The utilization of molecular markers in the target genes in marker-assisted selection (MAS) in genetic breeding programs can be more efficient than the utilization of linked markers. The advantage of these specific markers is that they are not loosed during recombination, besides being possible to use them practically in all relative populations as a way of general screening in elite breeding lines or germplasm banks (Mackill and McNally, 2006).

Many times the conversion of restriction fragment length polymorphism probes or single nucleotide polymorphism markers in specific PCR markers results in dominant markers. One of the limiting factors of the utilization of dominant markers is the single amplification of the fragment corresponding to the allele under study, and the absence of alternative allele amplification, generating a common result of presence and absence of a band in gel analysis. Therefore, failures in PCR or the non-amplification can be interpreted as an allele absence. This interpretation of false negative implies in reduced efficiency in the MAS in genetic breeding programs and loss of valuable genetic material. An alternative to avoid these problems is the utilization of an internal amplification control.

Biotechnological advances have increased the selection efficiency and productivity gains (Langridge and Fleury, 2011; Walsh et al., 2017; De Ron et al., 2017). The noncompetitive internal amplification control is a DNA sequence that is amplified in all samples and co-amplified in the same PCR of the target sample. Adding an internal amplification control, the control sign will be produced even if the target sequence is not present. This implies result interpretation safety, reduction of reaction problems by secondary structures, and elimination of false negatives (Hoorfar et al., 2004; Ma and Michaeliedes, 2006). However, PCRs with internal amplification control are still a challenge because several parameters need to be optimized such as the choice of an internal amplification control that can be amplified in all samples. Therefore, this DNA sequence needs to be preserved in the target species and cannot be polymorphic within the studied population. It is also necessary that amplicons have a different size to make fragment visualization easy. Besides that, the relationship between the target DNA concentrations and primers needs to be optimized to avoid competition by nucleotides in PCR, the formation of dimers and clamps between primers that will be co-amplified should be avoided, and reagents and conditions for PCR need to be optimized (Abdulmawjood et al., 2002; Hoorfar et al., 2004). Several research groups use internal amplification control to ensure reliability of their results (Henegariu et al., 1997; Narvel, 2000; Abdulmawjood et al., 2002; Loridon et al., 2005; Kanchana-Udomkan, 2013), but each internal amplification control needs to be optimized regarding the specific gene and the population of interest.

Glu-D1 locus in wheat is associated with gluten strengthening and breadmaking quality (Payne, 1987; Lukow et al., 1989; Shewry et al., 2003) and, therefore, it is interesting to incorporate this allele to new cultivars developed by genetic breeding programs. The Glu1-Dx5 marker is dominant, and the optimization of a biplex reaction using an internal amplification control can increase the efficiency of this marker in MAS breeding programs. In a comparison between singleplex and biplex PCR using internal amplification control, Masi et al. (2003) reported an economy of 50\% in PCR reagent utilization and $85 \%$ of electrophoresis costs. Therefore, this study aimed to evaluate the viability of a microsatellite marker as an internal amplification control with a dominant marker for the wheat Glul-Dx5 gene to avoid false-negative results.

Genetics and Molecular Research 16 (3): gmr16039718 


\section{MATERIAL AND METHODS}

\section{Vegetal material, DNA extraction, and quantification}

The experiments were done in seeds of 77 wheat cultivars/breeding lines of the genetic breeding program of the Central Cooperative of Agricultural Research (Coodetec) (Table 1).

\begin{tabular}{|c|c|c|c|c|c|}
\hline Genotype & Germplasm type & Genotype & Germplasm type & Genotype & Germplasm type \\
\hline CD0529 & Breeding line & CDI0602 & \begin{tabular}{|l} 
Breeding line \\
\end{tabular} & CD0711 & \begin{tabular}{|l} 
Breeding line \\
\end{tabular} \\
\hline CD0532 & Breeding line & CD0610 & Breeding line & CD0714 & Breeding line \\
\hline CD0568 & Breeding line & CD0614 & Breeding line & CD0715 & Breeding line \\
\hline CD0572 & Breeding line & CD0677 & Breeding line & CD0718 & Breeding line \\
\hline CD0574 & Breeding line & CD0712 & Breeding line & CD0721 & Breeding line \\
\hline CD0578 & Breeding line & CD0716 & Breeding line & CDI0408 & Breeding line \\
\hline CD0579 & Breeding line & CD0529 & Breeding line & CD0511 & Breeding line \\
\hline CD0622 & \begin{tabular}{|l|} 
Breeding line \\
\end{tabular} & \begin{tabular}{|l|} 
CD0544 \\
\end{tabular} & Breeding line & CD0513 & Breeding line \\
\hline CD0664 & \begin{tabular}{|l|} 
Breeding line \\
\end{tabular} & \begin{tabular}{|l|} 
CD0651 \\
\end{tabular} & Breeding line & CD0515 & Breeding line \\
\hline CD0665 & \begin{tabular}{|l|} 
Breeding line \\
\end{tabular} & \begin{tabular}{|l|} 
CD0654 \\
\end{tabular} & Breeding line & SAFIRA & Cultivar \\
\hline CD0666 & Breeding line & CD0658 & Breeding line & BRS208 & Cultivar \\
\hline CD0671 & Breeding line & CD0660 & Breeding line & IPR85 & Cultivar \\
\hline CD0674 & Breeding line & CD0661 & Breeding line & CD104 & Cultivar \\
\hline CD0680 & Breeding line & CD0667 & Breeding line & CD105 & Cultivar \\
\hline CD0684 & Breeding line & CD0669 & Breeding line & CD106 & Cultivar \\
\hline CDF2002116 & Breeding line & CD0678 & Breeding line & CD108 & Cultivar \\
\hline CD0619 & Breeding line & CD0683 & Breeding line & CD110 & Cultivar \\
\hline CD0620 & Breeding line & CD0627 & Breeding line & CD111 & Cultivar \\
\hline CD0644 & Breeding line & CD0631 & Breeding line & CD112 & Cultivar \\
\hline CD0646 & Breeding line & CD0632 & Breeding line & CD113 & Cultivar \\
\hline CD0647 & Breeding line & CD0545 & Breeding line & CD114 & Cultivar \\
\hline CD0649 & \begin{tabular}{|l|} 
Breeding line \\
\end{tabular} & \begin{tabular}{|l|} 
CD0548 \\
\end{tabular} & \begin{tabular}{|l|} 
Breeding line \\
\end{tabular} & CD116 & Cultivar \\
\hline CD0542 & \begin{tabular}{|l|} 
Breeding line \\
\end{tabular} & \begin{tabular}{|l|} 
CD0672 \\
\end{tabular} & \begin{tabular}{|l|} 
Breeding line \\
\end{tabular} & CD117 & \begin{tabular}{|l} 
Cultivar \\
\end{tabular} \\
\hline CD0558 & Breeding line & CD0683 & Breeding line & ONIX & Cultivar \\
\hline CD0559 & \begin{tabular}{|l|} 
Breeding line \\
\end{tabular} & CD0704 & Breeding line & \multirow[t]{2}{*}{ Fundacep Nova Era } & \multirow[t]{2}{*}{ Cultivar } \\
\hline CD0706 & Breeding line & CD0705 & Breeding line & & \\
\hline
\end{tabular}

A sample of 50 seeds of each cultivar/breeding line was ground in an MA 630 grinder $\left(\right.$ Marconi $^{\mathbb{\Xi}}$ ) and submitted to DNA extraction following the protocol described by McDonald et al. (1994), with modifications (Schuster et al., 2004). In 1.5-mL microtubes containing approximately $50 \mathrm{mg}$ ground seeds, $500 \mu \mathrm{L}$ of an extraction buffer solution containing $0.1 \mathrm{M}$ Tris- $\mathrm{HCl}(\mathrm{pH} \mathrm{7.5)}$, $5 \mathrm{M} \mathrm{NaCl}, 5 \mathrm{M}$ EDTA, and 10\% SDS was added. A 3-mm diameter glass ball was placed in each tube followed by maceration in a grinder $\left(\mathrm{ACS}^{\circledR}\right)$, the addition of $500 \mu \mathrm{L}$ extraction buffer, homogenization by Vortex agitator, and centrifugation at 18,506 $\mathrm{g}$ for $10 \mathrm{~min}$. After centrifugation, the supernatant was transferred to a new tube with $10 \mu \mathrm{L}$ proteinase $\mathrm{K}(10 \mathrm{mg} / \mathrm{mL})$ and immersed in water at $37^{\circ} \mathrm{C}$ for $30 \mathrm{~min}$. Next, $500 \mu \mathrm{L}$ cold isopropanol was added, and the tubes were maintained at rest for $2 \mathrm{~min}$ and centrifuged for $15 \mathrm{~min}$ at 18,506 $\mathrm{g}$. The supernatant was discarded, the precipitate was dried at ambient temperature for $15 \mathrm{~min}$, resuspended in $300 \mu \mathrm{L}$ TE buffer $(0.1$ $\mathrm{M}$ Tris- $\mathrm{HCl}$, pH 7.5 and $5 \mathrm{M}$ EDTA) with RNase A ( $40 \mu \mathrm{g} / \mu \mathrm{L})$ and immersed in water at $37^{\circ} \mathrm{C}$ for $30 \mathrm{~min}$. DNA was again precipitated by adding $500 \mu \mathrm{L}$ cold isopropanol, maintained at rest for 2 $\mathrm{min}$ and centrifuged for $15 \mathrm{~min}$ at $18,506 \mathrm{~g}$. The supernatant was discarded, and the precipitate was dried at ambient temperature and resuspended in $300 \mu \mathrm{L}$ TE buffer.

The DNA concentration of each sample was estimated by absorbance at $260 \mathrm{~nm}$ in a Nanodrop 1000 spectrophotometer. Every absorbance unit corresponded to $50 \mu \mathrm{g} / \mathrm{mL}$ doublestranded DNA (Sambrook et al., 1989). 


\section{In silico selection for internal amplification control}

To verify the best internal control, 14 microsatellite markers of wheat (Table 2) with amplicons varying from 180 up to $240 \mathrm{bp}$ were evaluated regarding the formation of clamps and dimers with primers of the Glu1-Dx5 marker ( $450 \mathrm{bp}$ ) by aligning its sequences utilizing the Netprimer program $<\mathrm{http}: / / \mathrm{www}$.netprimer.com $>$. The primer sequences are available in the link $<\mathrm{http} / / /$ wheat.pw.usda.gov/CGI-bin/graingenes/SSRsize $>$. The primers that presented clamps and/or dimers after the analysis were discarded due to a greater chance of nonamplification of the target DNA.

Table 2. Microsatellite markers (SSR) utilized in in silico analysis to verify the formation of secondary structures with a dominant marker for the Glu1-Dx5 gene.

\begin{tabular}{l|c|l}
\hline SSR marker & Amplicon (bp) & In silico analysis \\
\hline Xbarc51 & 227 & No dimer/clamp \\
\hline Xbarc79 & 95 & 5 dimers \\
\hline Xbarc84 & 110 & 6 clamps \\
\hline Xbarc102 & 188 & No dimer/clamp \\
\hline Xbarc117 & 223 & No dimer/clamp \\
\hline Xbarc125 & 175 & No dimer/clamp \\
\hline Xbarc133 & 127 & No dimer/clamp \\
\hline Xbarc145 & 164 & 5 dimers \\
\hline Xbarc158 & 248 & 3 dimers \\
\hline Xbarc119 & 208 & No dimer/clamp \\
\hline Xbarc187 & 258 & 5 dimers \\
\hline Xbarc169 & 115 & No dimer/clamp \\
\hline Xbarc162 & 192 & 4 dimers \\
\hline Xbarc148 & 196 & No dimer/clamp \\
\hline
\end{tabular}

\section{Amplification and electrophoresis}

The wheat cultivars Frontana and Ocepar22 were used as negative and positive controls, respectively, for PCR amplification and allele identification. The primer pair of Glu1-Dx5 markers was developed by Anderson et al. (1998) and has the following sequences: 5'-GCCTAGCAACCTTCACAATC-3' and 5'-GAAACCTGCTGCGGACAAG-3'.

PCRs were done in a Verit thermocycler (Applied Biosystems ${ }^{\circledR}$ ) in $0.2-\mathrm{mL}$ microtubes with a total volume of $20 \mu \mathrm{L}$ containing 1 X PCR buffer ( $20 \mathrm{mM}$ Tris-HCl, $50 \mathrm{mM} \mathrm{KCl}), 2$ or 3 $\mathrm{mM} \mathrm{MgCl} 2,250 \mathrm{mM}$ dNTP, $75 \mathrm{ng}$ DNA, and primers at the concentration of $0.2 \mu \mathrm{M}$. The PCRs were done in biplex with microsatellite primer and specific primer for the Glu1-Dx5 gene.

Two different concentrations of magnesium chloride at 2 and $3 \mathrm{mM}$ were tested at different annealing temperatures: $51^{\circ}, 53^{\circ}, 55^{\circ}, 57^{\circ}$, and $59^{\circ} \mathrm{C}$ utilizing different amplification conditions: initial cycle at $94^{\circ} \mathrm{C}$ for $5 \mathrm{~min}, 94^{\circ} \mathrm{C}$ of denaturation for $60 \mathrm{~s}$, annealing for $30 \mathrm{~s}$ at the temperatures cited before, extension of $72^{\circ} \mathrm{C}$ for $60 \mathrm{~s}$ during 45 cycles, and a final cycle of $72^{\circ} \mathrm{C}$ for $10 \mathrm{~min}$.

After the amplification, PCR fragments were separated by electrophoresis on 3\% agarose gel with ethidium bromide $(1 \mu \mathrm{g} / \mathrm{mL})$. The fragments were visualized under ultraviolet light in a Vilber Lourmat photo-documentation device (Marne La Valle ${ }^{\circledR}$ ).

The PCR program that produced results without non-specificity amplification such as faint, fuzzy, or smeared bands was selected to amplify all 77 samples.

Genetics and Molecular Research 16 (3): gmr16039718 


\section{RESULTS AND DISCUSSION}

Among the 14 in silico microsatellite markers with the Glu1-Dx5 marker analyzed in the Netprimer program, six presented dimers or clamps and were excluded from the study. Among the remaining markers, Xbarc117 was the most monomorphic within this population and, therefore, selected to continue this study. The in silico alignment for the analysis of the possible formation of secondary structures such as dimers and clamps has not been reported in previous studies (Henegariu et al., 1997; Narvel, 2000; Loridon et al., 2005) and can compromise the success of PCRs. Moreover, in silico analysis saves time and reagents, and is an important factor to quickly reach the aims of studies with great amounts of samples.

The concentration of $3 \mathrm{mM} \mathrm{MgCl}$ at an annealing temperature of $57^{\circ} \mathrm{C}$ was the most effective simultaneous amplification with neat bands without non-specific bands such as smeared or phantom bands. The bands were of the expected fragment sizes of $223 \mathrm{bp}$ for Xbarc117 and $450 \mathrm{bp}$ for Glu1-Dx5. The amplification in this condition makes possible to analyze the presence and absence of high molecular weight (HMW) glutenin alleles, excluding false negatives. The annealing temperatures at $51^{\circ}, 53^{\circ}, 55^{\circ}$, and $59^{\circ} \mathrm{C}$ were not promising. The annealing temperature of $57^{\circ} \mathrm{C}$ presented the best result for the amplification of the Glu1-Dx5 marker in the cultivar Ocepar 22 (Figure 1H). This temperature is closer to the optimal temperature of the Xbarc117 marker $\left(54.4^{\circ}-55^{\circ} \mathrm{C}\right)$ than $G l u 1-D x 5$ marker $\left(63^{\circ}-65^{\circ} \mathrm{C}\right)$. The positive and negative controls, cultivars Ocepar 22 and Frontana, were properly amplified with the annealing temperature of $57^{\circ} \mathrm{C}$. This PCR condition, with $3 \mathrm{mM} \mathrm{MgCl}$, and an annealing temperature of $57^{\circ} \mathrm{C}$ also works well when both markers were used in the biplex amplification (Figure 2).

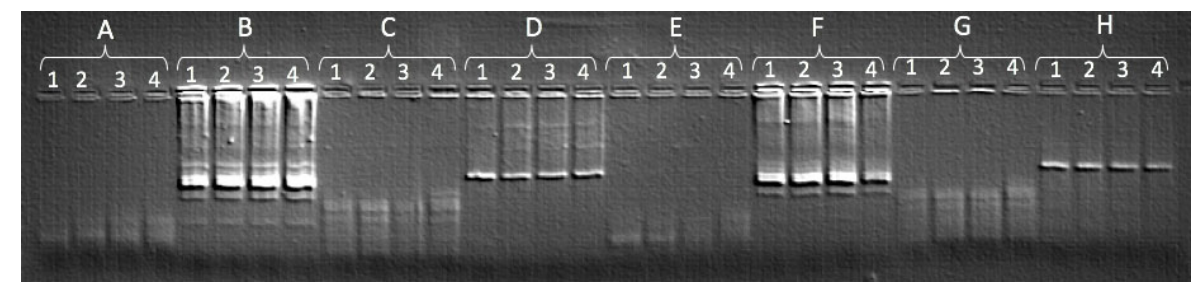

Figure 1. PCR amplification of the Glu1-Dx5 marker in the cultivar Ocepar22, with four replicates (lanes 1, 2, 3, and 4 ), at different concentrations of $\mathrm{MgCl}_{2}(2$ and $3 \mathrm{mM})$ and annealing temperatures $\left(51^{\circ}, 53^{\circ}, 55^{\circ}, 57^{\circ}\right.$, and $\left.59^{\circ} \mathrm{C}\right)$.

Annealing temperature and $\mathrm{MgCl}_{2}$ concentration: $\mathrm{A}=51^{\circ} \mathrm{C}$ and $2 \mathrm{mM}, \mathrm{B}=51^{\circ} \mathrm{C}$ and $3 \mathrm{mM}, \mathrm{C}=53^{\circ} \mathrm{C}$ and $2 \mathrm{mM}, \mathrm{D}=53^{\circ} \mathrm{C}$ and $3 \mathrm{mM}, \mathrm{E}=55^{\circ} \mathrm{C}$ and $2 \mathrm{mM}, \mathrm{F}=55^{\circ} \mathrm{C}$ and $3 \mathrm{mM}$, $\mathrm{G}=57^{\circ} \mathrm{C}$ and $2 \mathrm{mM}$, and $\mathrm{H}=57^{\circ} \mathrm{C}$ and $3 \mathrm{mM}$.

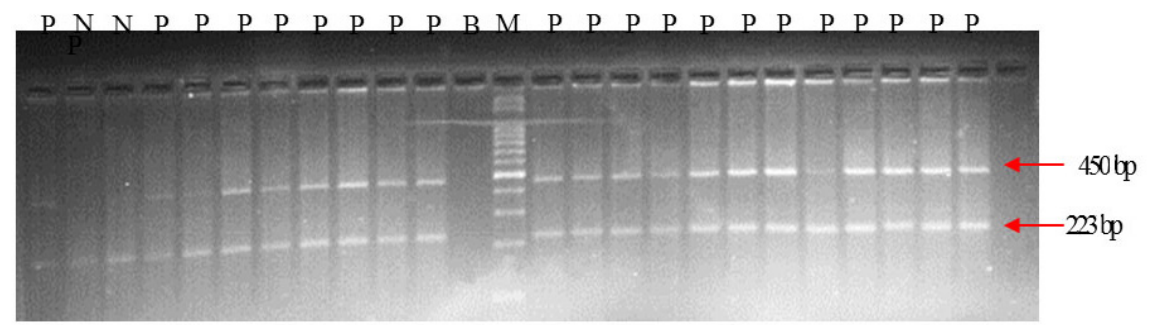

Figure 2. Biplex PCR amplification with primers Glu1-Dx5 (450 bp) and Xbarc117 (223 bp). Lanes $P=$ positive for Glu1-Dx5; lanes $N=$ negative for Glu1-Dx5; lane $M=100$-bp molecular marker; lane $B=$ negative control without DNA.

Genetics and Molecular Research 16 (3): gmr16039718 
Paro (2011) observed that of the 77 individuals analyzed, only 62 presented the Glu1Dx5 allele amplified after standard PCR analysis. However, the same author, after analyzing the same samples by SDS-PAGE, verified the presence of the Glu1-Dx5 subunit in 66 samples. Thus, PCR analysis with dominant markers without the presence of an internal reaction control, despite being practical, is limited and less effective.

In our study, the same 77 samples utilized by Paro (2011) were evaluated, and the presence of the Glu1-Dx5 allele was verified in the 66 individuals that presented Glu1-Dx5 subunit of HMW glutenin. Also, the presence of the Xbarc117 marker was observed in all 77 samples of the population without false-negative results or non-specific amplification bands. This suggests that the PCR simultaneous amplification with Glu1-Dx5 and Xbarc117 markers was effective and the internal amplification control (Xbarc117) is valuable with the dominant marker for the wheat Glu1-Dx5 gene. Besides, this molecular analysis can reduce the analysis time and increase the reliability of results obtained by PCR.

\section{CONCLUSION}

The Xbarc117 microsatellite marker can be amplified and detected with or without the dominant marker for the Glu1-Dx5 gene in different wheat cultivars/breeding lines and is valuable as an internal control for PCR.

\section{Conflicts of interest}

The authors declare no conflict of interest.

\section{ACKNOWLEDGMENTS}

The authors thank Paranaense University, the Postgraduate Program of Biotechnology applied to Agriculture and the Central Cooperative of Agricultural Research.

\section{REFERENCES}

Abdulmawjood A, Roth S and Bülte M (2002). Two methods for construction of internal amplification controls for the detection of Escherichia coli $\mathrm{O} 157$ by polymerase chain reaction. Mol. Cell. Probes 16: 335-339. https://doi. org/10.1006/mcpr.2002.0431

Anderson OD, Pierce FA and Tam A (1998). Conservation in wheat high-molecular-weight glutenin gene promoter sequences: comparisons among loci and among alleles of the GLU-B1-1 locus. Theor. Appl. Genet. 96: 568-576. https://doi.org/10.1007/s001220050775

DeRon AM, Sparvoli F, Pueyo JJ and Bazile D (2017). Protein crops: food and feed for the future. Front. Plant Sci. 8: 1-15.

Henegariu O, Heerema NA, Dlouhy SR, Vance GH, et al. (1997). Multiplex PCR: critical parameters and step-by-step protocol. Biotechniques 23: 504-511.

Hoorfar J, Malorny B, Abdulmawjood A, Cook N, et al. (2004). Practical considerations in design of internal amplification controls for diagnostic PCR assays. J. Clin. Microbiol. 42: 1863-1868. https://doi.org/10.1128/JCM.42.5.1863$\underline{1868.2004}$

Kanchana-Udomkan C (2013). Molecular markers in papaya. In: Genetics and genomics of papaya (Ming R and Moore $\mathrm{PH}$, eds.). Springer, Berlin.

Langridge P and Fleury D (2011). Making the most of 'omics' for crop breeding. Trends Biotechnol. 29: 33-40. https://doi. org/10.1016/j.tibtech.2010.09.006

Loridon K, McPhee K, Morin J, Dubreuil P, et al. (2005). Microsatellite marker polymorphism and mapping in pea (Pisum sativum L.). Theor. Appl. Genet. 111: 1022-1031. https://doi.org/10.1007/s00122-005-0014-3

Genetics and Molecular Research 16 (3): gmr16039718 
Lukow OM, Payne PI and Tkachuk R (1989). The HMW glutenin subunit composition of Canadian wheat cultivars and their association with bread-making quality. J. Sci. Food Agric. 46: 451-460. https://doi.org/10.1002/jsfa.2740460407

Ma Z and Michaeliedes TJ (2006). Approaches for eliminating PCR inhibitors and designing PCR primers for the detections of phytopathogenic fungi. Crop Prot. 26: 145-161. https://doi.org/10.1016/j.cropro.2006.04.014

Mackill JD and McNally KL (2006). Gene mapping with molecular markers in rice. In: Molecular marker systems in plant breeding and crop Improvement (Lörz H and Wenzel G, eds.). Springer, Berlin.

Masi P, Zeuli PLS and Donini P (2003). Development and analysis of multiplex microsatellite markers sets in common bean (Phaseolus vulgaris L.). Mol. Breed. 11: 303-313. https://doi.org/10.1023/A:1023443109985

McDonald MB, Elliot LJ and Sweeney MP (1994). DNA extraction from dry seeds for RAPD analyses in varietal identification studies. Seed Sci. Technol. 22: 171-176.

Narvel MJ (2000). Development of multiplex sets of simple sequence repeat DNA markers covering the soybean genome. Mol. Breed. 6: 175-183. https://doi.org/10.1023/A:1009637119947

Paro P (2011). Associação de gluteninas de alta massa molecular e qualidade de panificação em trigo: análise de proteínas e marcadores moleculares. Master's thesis. State University of West of Paraná, Marechal Cândido Rondon. Available at [http://tede.unioeste.br/tede//tde_arquivos/3/TDE-2012-03-08T112556Z-697/Publico/Patricia_Paro.pdf].

Payne PI (1987). Genetics of wheat storage proteins and the effect of allelic variation on bread-making quality. Annu. Rev. Plant Physiol. 38: 141-153. https://doi.org/10.1146/annurev.pp.38.060187.001041

Sambrook J, Frisch EF and Maniatis T (1989). Molecular cloning. A laboratory manual. 1st edn. Cold Spring Harbor Laboratory, New York.

Schuster I, Queiroz VT, Teixeira AI, Barros EG, et al. (2004). Determinação da pureza varietal de sementes de soja com auxílio de marcadores moleculares microssatélites. Pesqui. Agropecu. Bras. 39: 247-253. https://doi.org/10.1590/ $\underline{\text { S0100-204X2004000300007 }}$

Shewry PR, Popineau Y, Lafiandra D and Belton P (2003). Wheat glutenin subunits and dough elasticity: findings of the Eurowheat project. Trends Food Sci. Technol. 11: 433-441. https://doi.org/10.1016/S0924-2244(01)00035-8

Walsh AM, Crispie F, Claesson MJ and Cotter PD (2017). Translating omics to food microbiology. Annu. Rev. Food Sci. Technol. 8: 113-134. https://doi.org/10.1146/annurev-food-030216-025729

Genetics and Molecular Research 16 (3): gmr16039718 